\title{
Morbilliviral infections in marine mammals ${ }^{1}$
}

\author{
SEAMUS KENNEDY \\ V'eterinary Sciences Division, Department of Agriculture for Northern Ireland, Stoney \\ Road, Stormont, Belfast BT4 3SD, Northern Ireland
}

\begin{abstract}
Epizootics of infectious disease were unknown in cetaceans prior to 1987. However, since then there have been at least three epizootics in dolphins and two in pinniped species. Many of the clinical, pathological and epidemiological features of these events were similar to those of morbilliviral infections in terrestrial mammals. There has been speculation that contaminants may have predisposed marine mammals to these and this is discussed. Morbilliviruses are highly pathogenic viruses and caused epizootics in terrestrial mammals long before the advent of anthropogenic contaminants.
\end{abstract}

KEYWORDS: POLLUTION; DISEASE; EPIZOOTICS; IMMUNOSUPPRESSION; PATHOLOGY; PINNIPEDS; STRIPED DOLPHIN; HARBOUR PORPOISE; BOTTLENOSE DOLPHIN; WHITE WHALE; REVIEW

\section{REPORTED INFECTIONS}

Recognised morbillivirus infections had not been reported in aquatic mammals prior to 1987 , but since then there have been a number of epizootics of morbilliviral disease in cetacean and pinniped populations in several regions of the world (e.g. Simmonds, 1992).

\section{Pinnipeds}

An epizootic of morbillivirus infection killed approximately 18,000 harbour seals (Phoca vitulina) and several hundred grey seals (Halichoerus grypus) in Europe in 1988 (Kennedy et al., 1988b; Osterhaus and Vedder, 1988; Dietz et al., 1989; Bergman et al., 1990; Kennedy, 1990). This die-off apparently began along the Baltic coast in April of that year and subsequently spread to seal colonies along the North Sea coasts of Norway, Sweden, Denmark, Germany, The Netherlands, the United Kingdom and Ireland. It appears to have terminated in late 1988 although a small localised outbreak occurred in northern Norway in late 1989 (Krogsrud et al., 1990). In addition, a morbilliviral epizootic killed several thousand Baikal seals (Phoca sibirica) in Lake Baikal from late 1987 to late 1988 (Grachev et al., 1989).

Laboratory studies (Cosby et al., 1988; Curran et al., 1990; Blixenkrone-Moller et al., 1992; Rima et al., 1992) indicated that the morbillivirus which infected European seals was a newly recognised virus (the phocine distemper virus, PDV). Similar studies of a virus isolated from Lake Baikal seals (Osterhaus et al., 1989; Visser et al., 1990; Barrett et al., 1992) indicated that it was a strain of canine distemper virus (CDV). No epidemiological link could therefore be established between the Siberian and European epizootics.

1 This paper was originally submitted to the IWC Scientific Committee as SC/M95/P15. 


\section{Cetaceans}

The first evidence of morbillivirus infection in cetaceans emerged from the coast of Ireland during the 1988 European seal epizootic. At that time a morbillivirus disease was diagnosed in six harbour porpoises (Phocoena phocoena) found stranded on the coast of Northern Ireland (Kennedy et al., 1988a; 1991). Morbilliviral disease was subsequently found in a few harbour porpoises found stranded on the coasts of England, Scotland and The Netherlands in 1990 (Kennedy et al., 1992; Visser et al., 1993). As the porpoises from the coast of Northern Ireland were found in a region inhabited by morbillivirus-infected harbour seals, it was originally believed that interspecific transmission of PDV had occurred. However, the porpoise morbillivirus was subsequently isolated and characterised as another newly discovered morbillivirus distinct from PDV (McCullough et al., 1991; Welsh et al., 1992; Barrett et al., 1993; Visser et al., 1993; Blixenkrone-Moller et al., 1994).

A die-off of striped dolphins (Stenella coeruleolba) began along the Mediterranean coast of Spain in July 1990 (Domingo et al., 1990; 1992; Duignan et al., 1992). This epizootic rapidly spread to other areas of the Spanish and French Mediterranean coasts and probably also to the coasts of Morocco and Algeria. It subsided in late 1990 but re-emerged along the southern coast of Spain between June and September 1991 and eventually reached the southern Adriatic Sea, Ionian Sea, Sicilian Channel and southern Tyrrhenian Sea. A third outbreak occurred in the region of the Greek Islands in early 1992. At least several thousand animals are believed to have died during these Mediterranean outbreaks (Di Guardo et al., 1992; 1995; Aguilar and Raga, 1993). Laboratory characterisation of a morbillivirus isolated from affected dolphins in the western, central and eastern regions of the Mediterranean Sea indicated that all three outbreaks were phases of a single epizootic (Van Bressem et al., 1993).

It has been suggested that the northwestern European harbour porpoise and Mediterranean striped dolphin viruses may represent two distinct strains of the same morbillivirus (Bolt and Blixenkrone-Moller, 1994). Antigenic and genomic analyses indicate that the viruses isolated from these cetaceans are distinct from other morbilliviruses including the newly recognised PDV (Curran et al.. 1990; 1992; McCullough et al., 1991: Welsh et al., 1992; Barrett et al., 1993; Van Bressem et al., 1993; Visser et al., 1993; Blixenkrone-Moller et al., 1994; Bolt and Blixenkrone-Moller, 1994). Although they cause a distemper-like disease in harbour porpoises and striped dolphins (Kennedy et al., 1988a; 1991; 1992; Domingo et al., 1992; Duignan et al., 1992), the cetacean morbilliviruses appear to be more closely related to rinderpest, peste-des-petits-ruminants and measles viruses than to CDV and PDV, which comprise the distemper subgroup of morbilliviruses (Visser et al., 1993).

From June 1987 until May 1988, hundreds of Atlantic bottlenose dolphins (Tursiops truncatus) died along the eastern coast of the United States. Strandings commenced along the coast of New Jersey and eventually spread to the Atlantic coast of Florida. It has been estimated that more than $50 \%$ of the inshore population of bottlenose dolphins in this region died (Federal Register, 1993).

An initial investigation concluded that brevetoxin produced by the 'red tide' marine dinoflagellate Ptychodiscus brevis was the main cause of the die-off (Geraci, 1989). However, a recent study of tissues from affected animals revealed the presence of morbillivirus infection and associated lesions in more than $50 \%$ of animals examined (Lipscomb et al., 1994b).

The most recent known epizootic of morbillivirus disease in cetaceans occurred among bottlenose dolphins in the Gulf of Mexico from June 1993 to mid-1994. This mortality event evolved slowly but eventually affected dolphins from Florida to Texas. The full extent of dolphin mortality in this incident is unknown (Lipscomb et al., 1994a). 
Virus isolation or genomic analysis of the morbillivirus present in tissues of bottlenose dolphins from the western Atlantic and Gulf of Mexico epizootics has not been achieved. It is therefore not yet possible to determine the relationships of the morbillivirus or morbilliviruses in these populations to those affecting the harbour porpoise and striped dolphin populations referred to above.

\section{EPIDEMIOLOGY OF MARINE MAMMAL MORBILIIVIRUSES}

Epizootics of morbillivirus infection are believed to have occurred in terrestrial species from antiquity. Measles epidemics in humans date back to the early years of this millenium and waves of rinderpest have raged in large ruminant populations in Africa, Asia and Europe for centuries (Norrby and Oxman. 1990; Scott, 1990). Mortality rates have frequently approached $100 \%$. The epidemiology of these events and our knowledge of experimental morbilliviral infections in animals indicate that these viruses are highly pathogenic agents capable of causing very high mortality in susceptible populations. Since morbilliviral epidemics in terrestrial mammals obviously pre-date the manufacture of organochlorine compounds, it is apparent that these viruses can cause disease outbreaks of epidemic proportions in the absence of contaminants. The pathology of morbilliviral infection in aquatic mammals has been well documented and is very similar to that in terrestrial mammals (Kennedy et al., 1989; Norrby and Oxman, 1990; Domingo et al., 1992; Lipscomb et al., 1994b).

Extrapolating from our knowledge of the epidemiology of morbillivirus infections in terrestrial mammals, morbillivirus epizootics in marine mammals are likely to have resulted from the introduction of morbilliviruses to previously unexposed and therefore immunologically naive populations. Direct contact with an infected animal appears to be the probable method of introduction to a new population. Morbilliviruses frequently cause epizootics in susceptible host species (Norrby and Oxman, 1990; Scott, 1990). They are highly infectious and are excreted in large numbers by many routes including respiratory aerosol, and via a range of body secretions and excretions. Although they are relatively unstable in the environment, their low minimum infectious dose results in a high transmission rate provided the population density exceeds a minimum threshold value. It is therefore not surprising that such viruses can cause major epizootics in marine mammal species.

In non-exposed populations of terrestrial mammals, morbillivirus outbreaks usually affect individuals of all ages, while in those with previous exposure to the virus they predominantly affect young individuals with less developed immune systems (Hoffman, 1983). In the North Sea harbour seal epizootic and the Mediterranean striped dolphin epizootic, mortality centred on adult individuals as well as juveniles. The cause for apparent discrepancy in age-specific mortality in marine mammals between some areas remains unknown, although behavioural factors that would result in a lower exposure of juveniles to the virus have been suggested (Härkönen and Heide-Jørgensen, 1990; Calzada et al., 1994).

\section{IMMUNOSUPPRESSION IN MORBILLIVIRUS-INFECTED ANIMALS}

Lymphoid, epithelial and central nervous system tissues are the major host targets for morbilliviruses. Marked damage to lymphoid tissues has been demonstrated in a wide range of morbillivirus-infected terrestrial and marine mammals including cetaceans (Norrby and Oxman, 1990; Kennedy et al., 1991; Domingo et al., 1992; Duignan et al., 1992; Lipscomb et al., 1994b). The effects of this damage in natural infections are difficult to quantify but clinically significant immunosuppression in morbillivirus-infected marine mammals is 
evidenced by the destruction of lymphoid tissues and an increased incidence of secondary fungal, bacterial, protozoal and parasitic infections (Kennedy et al., 1989; 1991; Baker and Raga, 1992; Domingo et al., 1992; Duignan et al., 1992; Lipscomb et al., 1994a; b).

Our understanding of the epidemiology of the aquatic mammal epidemics is incomplete, but the rapid spread of infection and high mortality rates mirror morbilliviral infections in terrestrial animals. These similarities suggest that it is likely that the cause of the recent epizootics in marine mammals was the introduction of a virus into previously unexposed and therefore susceptible populations.

Although there is no evidence that contaminants facilitated recent morbillivirus epizootics in marine mammals, it is well known that organochlorines, including polychlorinated biphenyl compounds (PCBs), accumulate to high concentrations in tissues of marine mammals. These compounds have been demonstrated to reduce immune function in several terrestrial mammalian and avian species (Busbee et al., 1999). Furthermore, altered in vitro indices of immune function have been demonstrated experimentally in harbour seals fed fish from environmentally-contaminated waters (De Swart et al., 1994; 1995; Ross et al., 1995) and in vitro tests on bottlenose dolphin line cells have shown the capability of organochlorines to induce immune dysfunction in cetacean cells (Busbee et al., 1999). It is therefore likely that such substances could produce immunosuppression in wild marine mammals.

Several studies have attempted to identify a relationship between tissue levels of PCBs and mortality due to morbillivirus infection in marine mammals. For example, higher levels of PCBs were reported in tissues of seals that died during the 1988 European morbillivirus epizootic than in survivors (Hall et al., 1992), whilst exceptionally high concentrations of PCBs were found in tissues of striped dolphins that died during the die-off in the Mediterranean Sea in 1990 compared to concentrations in tissues of this species in years prior to and after this epizootic (Aguilar and Borrell, 1994). Tissue concentrations in bottlenose dolphins that died during the morbillivirus epizootic along the eastern coast of the USA in 1987 and 1988 were also considered to be high although comparisons could not be made with levels in tissues of surviving dolphins (Kuehl et al., 1991). However, under experimental conditions, exposure to PCBs did not increase the susceptibility of seals to morbilliviral disease (Harder et al., 1992).

In essence, these studies provide quantitative data on tissue pollutant concentrations and an indication that some pollutants cause alterations in in vitro indices of immune function. However, there is no evidence that they have affected mortality or morbidity due to morbilliviral infection. It should be recognised though, that discovery of a cause and effect relationship between tissue concentrations of contaminants and morbillivirus mortality in these epizootics would be difficult. As morbilliviruses cause direct damage to the immune system and are therefore likely to be a major cause of mortality in infected animals, it is clear that such immunosuppression and any resulting from contaminants will be difficult to quantify separately.

Detection of changes in the prevalence of such diseases can best be achieved by postmortem examination of affected individuals and subsequent correlation of lesions with tissue contaminant concentrations or biomarkers of the toxic effects of these substances. It is currently impossible to separate any possible immunosuppressive effects of contaminants from those due to morbillivirus infection in aquatic mammals that have died as a result of natural morbillivirus infections.

Morbilliviral epidemics are therefore unlikely to be the ideal scenario for investigating possible immunosuppressive effects of contaminants in marine mammals. Such effects are more likely to be insidious and manifest as an increase in susceptibility to neoplasms and diseases caused by organisms normally less pathogenic than morbilliviruses. As in human 
immunodeficiency virus infection and in morbilliviral infections in mammals, immunosuppression is associated with an increased incidence of opportunistic fungal, protozoal, bacterial and viral infections. An increase in the rate of neoplasms in a contaminated population, as reported in white whales (Delphinapterus leucas) in the St Lawrence Estuary (Martineau et al., 1988), may also be an indication of immunosuppression.

Many morbilliviral-infected bottlenose dolphins and striped dolphins were found in poor body condition (Geraci, 1989; Domingo et al., 1992). Mobilisation of blubber reserves in these animals probably resulted in increased plasma concentrations of organochlorines and a consequently increased risk of toxicity from these compounds. Mortality and morbidity during morbilliviral epizootics may therefore have been higher in dolphins with high body burdens of lipophilic contaminants than in those with lower tissue levels. However, given the lethal effects of morbilliviruses, it is this author's view that it is unlikely that organochlorine toxicity had anything other than a marginal effect on mortality.

In conclusion, the recent epizootics of morbilliviral infection in marine mammals are likely to have resulted from introduction of morbilliviral infection into susceptible populations. The high mortality reported in many of these die-offs is consistent with our knowledge of morbilliviral infections in terrestrial mammals. Although epizootics of infectious disease had not been reported in aquatic mammals prior to 1987 and many of the animals involved in recent die-offs had relatively high tissue concentrations of organochlorines, there is no evidence that contaminants contributed to increased mortality in these populations. However, the increasing data on potentially significant deleterious effects of contaminants on marine mammal health, i.e. immunosuppression, warrants further investigation.

\section{REFERENCES}

Aguilar, A. and Borrell, A. 1994. Abnormally high polychlorinated biphenyl levels in striped dolphins (Stenella coeruleoalba) affected by the 1990-1992 Mediterranean epizootic. Sci. Total Environ. 154(2-3):237-47.

Aguilar, A. and Raga, J.A. 1993. The striped dolphin epizootic in the Mediterranean Sea. Ambio 22(8):524-8.

Baker, J.R. and Raga, J.A. 1992. The role of bacteria in phocine distemper. Sci. Total Environ. 115:9-14.

Barrett. T. Crowther, J., Osterhaus, A.D.M.E., Subbarao, S.M., Groen, J., Haas, L., Mamaev, L., Titenko, A.M. Grachev, M.A., Visser, I.K.G. and Bostock, C.J. 1992. Molecular and serological studies on the recent seal virus epizootics in Europe and Siberia. Sci. Total Environ. 115:117-32.

Barrett, T., Visser, I.K.G., Mamaev, L., Goatley, L., Van Bressem, M.F. and Osterhaus, A.D.M.E. 1993. Dolphin and porpoise morbilliviruses are genetically distinct from phocine distemper virus. Virology 193:1010-2.

Bergman, A., Järplid, B. and Svensson, B.-M. 1990. Pathological findings indicative of distemper in European seals. Vet. Microbiol. 23:331-42.

Blixenkrone-Moller, M., Sharma, B., Versanyi, T.M., Hu, A., Norrby. E. and Kovamees, J. 1992. Sequence analysis of the genes encoding the nucleocapsid protein and phosphoprotein $(P)$ of phocid distcmper virus and editing of the P gene transcript. J. Gen. Vir. 73:885-93.

Blixenkrone-Moller, M., Bolt, G., Gottschalck, E. and Kenter, M. 1994. Comparative analysis of the gene encoding the nucleocapsid protein of dolphin morbillivirus reveals its distant evolutionary relationship to measles virus and ruminant morbilliviruses. J. Gen. Vir. 75:2829-34.

Bolt, G. and Blixenkrone-Moller, M. 1994. Nucleic acid hybridization analyses confirm the presence of a hitherto unknown morbillivirus in Mediterranean dolphins. Vet. Microbiol. 41(4):363-72.

Busbee, D., Tizard, I., Scott, J., Ferrick, D. and Ott-Reeves, E. 1999. Environmental pollutants and marine mammal health: the potential impact of hydrocarbons and halogenated hydrocarbons on immune system dysfunction. J. Cetacean Res. Manage. (special issue) 1:223-48.

Calzada, N., Lockyer, C.H. and Aguilar, A. 1994. Age and sex composition of the striped dolphin die-off in the western Mediterranean. Mar. Mammal Sci. 10(3):299-310. 
Cosby, S.L., McQuaid, S., Duffy, N., Lyons, C., Rima, B.K., Allan, G.M., McCulloch, S.J., Kennedy, S., Smyth, J.A., McNeilly, F., Craig, C. and Orvell, C. 1988. Characterization of a seal morbillivirus. Nature, Lond. 336:115-6.

Curran, M.D., O'Loan, D., Kennedy, S. and Rima, B.K. 1990. Nucleotide sequence analysis of phocine distemper virus reveals its distinctness from canine distemper virus. Vet. Rec. 127:430-1.

Curran, M.D., O'Loan, D., Kennedy, S. and Rima, B.K. 1992. Molecular characterisation of phocine distemper virus: gene order and sequence of the gene encoding the attachment (H) protein. I. Gen. Vir. 73:1189-94.

De Swart, R.L., Ross, P.S., Vedder, L.J., Timmerman, H.H., Heisterkamp, S.H., Van Loveren, H., Vos, J.G., Reijnders, P.J.H. and Osterhaus, A.D.M.E. 1994. Impairment of immune function in harbour seals (Phoc'a vitulina) feeding on fish from polluted waters. Ambio 23:155-9.

De Swart, R.L., Ross, P.S., Timmerman, H.H., Vos, H.W., Reijnders, P.J.H., Vos, J.G. and Osterhaus, A.D.M.E. 1995. Impaired cellular immune response function in harbour seals (Phoca vitulina) feeding on environmentally contaminated herring. Clin. Exper. Immunol. 101:480-6. Copy in Publications 1995, Erasmus Universiteit Rotterdam, Zeehondencreche pieterburen.

Dietz. R., Heide-Jørgensen, M.-P. and Härkönen, T. 1989. Mass deaths of harbor seals (Phoca vitulina) in Europe. Ambio 18(5):258-64.

Di Guardo, G., Agrimi, U.. Amaddeo, D., McAliskey, M. and Kennedy, S. 1992. Morbillivirus infection in a striped dolphin (Stenella coeruleoalha) from the coast of Italy. Vet. Rec. 130(26):579-80.

Di Guardo, G.. Agrimi, U., Morelli, L., Cardeti, G.. Terracciano, G. and Kennedy, S. 1995. Post mortem investigations on cetaceans found stranded on the coasts of Italy between 1990 and 1993. let. Rec. 136(17):439-42.

Domingo, M., Ferrer, L., Pumarola, M., Marco, A., Plana, J., Kennedy, S., McAliskey, M. and Rima, B.K. 1990. Morbillivirus in dolphins. Nature, Lond. 336:21.

Domingo, M., Visa, J., Pumarola, M., Marco, A.J., Ferrer, L., Rabanal, R. and Kennedy, S. 1992. Pathologic and immunocytochemical studies of morbillivirus infection in striped dolphins (Stenella coeruleoalha). liet. Pathol. 29:1-10.

Duignan, P.J., Geraci. J.R., Raga, J.A. and Calzalda, N. 1992. Pathology of morbillivirus infection in striped dolphins (Stenella coeruleoalba) from Valencia and Murcia, Spain. Can. J. Vet. Res. 56:242-8.

Federal Register. 1993. Vol. 58, Number 64. US Government Printing Office. Washington, DC. pp. 17,789-17,791.

Geraci, J.R. 1989. Clinical investigation of the 1987-88 mass mortality of bottlenose dolphins along the US central and south Atlantic coast. Final report to National Marine Fisheries Service and US Navy Office of Naval Research, and Marine Mammal Commission, Guelph, Ontario, Canada. 63pp.

Grachev, M.A., Kumarev, V.P., Mamaev, L.V., Zorin, V.L., Baranova, L.V., Denikina, N.N., Belikov, S.I.. Petrov, E.A., Kolesnik, V.S., Kolesnik, R.S.. Dorofeev, V.M., Beim, A.M., Kudelin, V.N., Nagieva, F.G. and Sidorov, V.N. 1989. Distemper virus in Baikal seals. Nature, Lond. 338:209-10.

Härkönen, T. and Heide-Jørgensen, M.-P. 1990. Short-term effects of the mass dying of harbour seals in the Kattegat-Skagerrak area during 1988. Z. Säugetierkd. 55(4):233-8.

Hall, A.J.. Law, R.J., Wells, D.E., Harwood, J., Ross, H., Kennedy, S., Allchin, C.R., Campbell, L.A. and Pomeroy, P.P. 1992. Organochlorine levels in common seals (Phoca vitulina) which werc victims and survivors of the 1988 phocine distemper epizootic. Sci. Total Environ. 115:145-62.

Harder, T.C., Willhaus, T., Leibold, W. and Leiss, B. 1992. Investigations on cause and outcome of phocine distemper infection in harbour seals (Phoca vitulina) exposed to polychlorinated biphenyls. $J$. Vet. Med. Sci. 39:19-31.

Hoffman, H. 1983. Rinderpest. pp. 161-71. In: J. Beer (ed.) Infektionskrankho'iten de' Haustiere. VEB Gustav Fischer Verlag, Jena.

Kennedy, S. 1990. A review of the 1988 European seal morbillivirus cpizootic. Let. Rec. 127:563-7.

Kennedy, S., Smyth. J.A., Cush, P.F., McCullough, S.J.. Allan, G.M. and McQuaid, S. 1988a. Viral distemper now found in porpoises. Nature 336(61941:21.

Kennedy, S., Smyth, J.A., McCullough. S.J., Allan, G.M., McNeilly, F. and McQuaid, S. 1988b. Confirmation of cause of recent seal deaths. Nature. Lond. 335(6189):404.

Kennedy, S., Smyth, J.A., Cush, P.F., Duignan, P., Platten, M.. McCullough, S.J. and Allan, G.M. 1989. Histopathologic and immunocytochemical studies of distemper in seals. let. Pathol. 26:97-103.

Kennedy, S., Smyth, J.A., Cush, P.F., McAliskey, M., McCullough, S.J. and Rima, B.K. 1991 Histopathology and immunocytochemical studies of distemper in harbor porpoises. let. Pathol. 28(1):1-7.

Kennedy, S., Kuiken, T., Ross, H.M., McAliskey, M., Moffett, D., MeNiven. C.M. and Carole, M. 1992. Morbillivirus infection in two common porpoises (Phococha phocoena) from the coasts of England and Scotland. Vet. Rec. 131(1.3):286-90. 
Krogsrud, J., Evensen, O., Holt, G., Hoie, S. and Markussen, N.H. 1990. Seal distemper in Norway in 1988 and 1989. Vet. Rec. 126:460-1.

Kuehl, D.W., Haebler, R. and Potter, C. 1991. Chemical residues in dolphins from the US Atlantic coast including Atlantic bottlenose obtained during the 1987-88 mass mortality. Chemosphere 22(11):1071-84.

Lipscomb, T.P.. Kennedy, S., Moffett, D. and Ford, B.K. 1994a. Morbilliviral disease in an Atlantic bottlenose dolphin (Tursiops truncatus) from the Gulf of Mexico. J. Wildl. Dis. 30(4):572-6.

Lipscomb, T.P., Schulman, F.Y., Moffett, D. and Kennedy, S. 1994b. Morbilliviral disease in Atlantic bottlenose dolphins (Tursiops truncatus) from the 1987-1988 epizootic. J. Wildl. Dis. 30(4):567-71.

Martineau, D., Lagacé, A., Béland, P., Higgins, R., Armstrong, D. and Shugart, L.R. 1988. Pathology of stranded beluga whales (Delphinapterus leucas) from St Lawrence estuary (Québec, Canada). J. Comp. Pathol. 38:287-311.

McCullough. S.J., McNeilly, F., Allan, G. M., Kennedy, S., Smyth, J.A., Cosby, S.L., McQuaid, S. and Rima, B.K. 1991. Isolation and characterisation of a porpoise morbillivirus. Arch. Virol. 118:247-52.

Norrby, E. and Oxman, M.N. 1990. Measles virus. pp. 1013-44. In: B.N. Fields and D.M. Knipe (eds.) I'irology. 2nd. Edn. Raven Press Ltd, New York.

Osterhaus, A.D.M.E. and Vedder, E.J. 1988. Identification of virus causing recent seal deaths. Nature, Lond. 335:20.

Osterhaus, A.D.M.E.. Groen, J.. UytdeHaag, F.G.C.M., Visser, I.K.G., van de Bildt, M.W.G., Bergman, A. and Klingeborn, B. 1989. Distemper virus in Baikal seals. Nature, Lond. 338:209-10.

Rima. B.K.. Curran, M.D. and Kennedy, S. 1992. Phocine distemper virus, the agent responsible for the 1988 mass mortality of seals. Sci. Total Environ. 115:45-55.

Ross, P.S., De Swart, R.L., Reijnders, P.J.H., Loveren, H.V., Vos, J.G. and Osterhaus, A.D.M.E. 1995. Contaminant related suppression of delayed-type hypersensitivity and antibody responses in harbour seals fed herring from the Baltic Sea. Environ. Health Perspect. 103(2):162-7.

Scott, G.R. 1990. Rinderpest Virus. pp. 341-54. In: Z. Dinter and B. Morein (eds.) Virus Infections of Ruminants. Vol. 3. Virus Infections of Vertebrates. Elsevier, Amsterdam.

Simmonds, M.P. 1992. Cetacean mass mortalities and their potential relationship with pollution. pp. $217-45$. In: J.J. Symoens (ed.) Symposium « Whales: Biology - Threats - Conservation». Royal Academy of Overseas Sciences, Brussels, Belgium. 261 pp.

Van Bressem, M.-F., Visser, I.K.G., De Swart, R.L., Orvell, C., Stanzani, I., Androukaki, E., Siakavara, K. and Osterhaus, A.D.M.E. 1993. Dolphin morbillivirus in different parts of the Mediterranean. Arch. Virol. 129:235-42.

Visser, I.K.G., Kumarev, V.P., Örvell, C., de Vries, P., Broeders, H.W.J., van de Bildt, M.W.G., Groen, J., Teppema, J.S., Burger, M.C., UytdeHaag, F.G.C.M. and Osterhaus, A.D.M.E. 1990. Comparison of two morbilliviruses isolated from seals during outbreaks of distemper in North West Europe and Siberia. Arch. Virol. 111:149-64.

Visser, I.K.G., van Bressem, M.F., de Swart, R.L., van de Bildt, M.W.G., Vos, H.W., van der Heijden, R.W.K., Saliki, J.T., Orvell, C., Kitching, P., Kuiken, T., Barrett, T. and Osterhaus, A.D.M.E. 1993. Characterisation of morbilliviruses isolated from dolphins and porpoises in Europe. J. Gen. Vir. 74:631-41.

Welsh, M.J., Lyons, C., Trudgett, A., Rima, B., McCullough, S.J. and Orvell, C. 1992. Characteristics of a cetacean morbillivirus isolated from a porpoise (Phocoena phocoena). Arch. Virol. 125(1-4):305-11. 